\title{
Increased MCP-1 and MIP-1 $\beta$ in bronchoalveolar lavage fluid of chronic bronchitics
}

\author{
A. Capelli*, A. Di Stefano*, I. Gnemmi*, P. Balbo ${ }^{+}$, C.G. Cerutti*, B. Balbi*, \\ M. Lusuardi*, C.F. Donner*
}

Increased MCP-1 and MIP-1 $\beta$ in bronchoalveolar lavage fluid of chronic bronchitics. $A$. Capelli, A. Di Stefano, I. Gnemmi, P. Balbo, C.G. Cerutti, B. Balbi, M. Lusuardi, C.F. Donner. (C) ERS Journals Ltd 1999.

ABSTRACT: CC-chemokines are chemotactic factors expressed in a wide range of cell types and tissues. The aim of this study was to evaluate the involvement of $\mathrm{CC}$ chemokines in the airways inflammation of patients affected by chronic bronchitis.

The study evaluated, with an immunoassay, the concentrations of monocyte chemotactic protein-1 (MCP-1), macrophage inflammatory protein-1 $\alpha(\mathrm{MIP}-1 \alpha)$ and macrophage inflammatory protein-1 $\beta$ (MIP-1 $\beta$ ), in the bronchoalveolar lavage fluid (BALF) of 12 smokers affected by chronic bronchitis and 14 smoking, 15 nonsmoking and six exsmoking healthy subjects.

MCP-1 was significantly increased in patients with chronic bronchitis ((mean \pm SD) $\left.10.75 \pm 4.04 \mathrm{pg} \cdot \mathrm{mL}^{-1}\right)$ and in the smoker control group $\left(12.39 \pm 5.87 \mathrm{pg} \cdot \mathrm{mL}^{-1}\right)$ compared with healthy exsmokers: $\left(7.12 \pm 1.60 \mathrm{pg} \cdot \mathrm{mL}^{-1}, \mathrm{p}=0.035\right.$ and $\mathrm{p}=0.045$, respectively) and nonsmokers $\left(6.41 \pm 3.87 \mathrm{pg} \cdot \mathrm{mL}^{-1}, \mathrm{p}=\mathbf{0 . 0 0 3}\right.$ and $\mathrm{p}=\mathbf{0 . 0 0 6}$, respectively). MIP-1 $\alpha$ concentrations were undetectable. A significant difference was observed in MIP-1- $\beta$ levels in BALF of chronic bronchitics $\left(8.11 \pm 5.97 \mathrm{pg} \cdot \mathrm{mL}^{-1}\right)$ compared to smoker $(3.57 \pm 2.90$ $\left.\mathrm{pg} \cdot \mathrm{mL}^{-1}, \mathrm{p}=\mathbf{0 . 0 1 8}\right)$, exsmoker $\left(3.43 \pm 0.68 \mathrm{pg} \cdot \mathrm{mL}^{-1}, \mathrm{p}=\mathbf{0 . 0 2 5}\right)$ and nonsmoker $(3.39 \pm 3.73$ $\left.\mathrm{pg} \cdot \mathrm{mL}^{-1}, \mathrm{p}=\mathbf{0 . 0 0 8}\right)$ control groups. A negative correlation was observed between MIP$1 \beta$ levels and forced expiratory volume in one second values $(\rho=-0.64, p=0.035)$ in chronic bronchitics.

An increase of monocyte chemotactic protein-1 is related to smoking habit and seems consistent with a lung inflammatory reaction. On the contrary, an increase in macrophage inflammatory protein- $1 \beta$ levels is restricted to smokers developing chronic obstructive pulmonary disease. These data suggest a role of $\mathrm{CC}$-chemokines in the pathogenesis of chronic bronchitis.

Eur Respir J 1999; 14: 160-165.
*Division of Pulmonary Disease, "Salvatore Maugeri" Foundation, IRCCS, Rehabilitation Institute of Veruno, Italy. ${ }^{+}$Division of Internal Medicine, AR USL 11 , Gattinara, Italy.

Correspondence: A. Capelli

Divisione di Pneumologia

Centro Medico di Riabilitazione

Veruno (Novara)

Italy

Fax: 390322830294

Keywords: Airways obstruction

bronchoalveolar lavage

chemokines

chronic bronchitis

tobacco smoke

Received: July 61998

Accepted after revision February 51999

The study was supported by grants: "Ricerca Corrente" from the Ministry of Health and "Ricerca Sanitaria Finalizzata" from Regione Piemonte, Torino, Italy.
Chemokines are low-molecular weight polypeptides that have been subdivided into $\mathrm{CXC}, \mathrm{CC}$ and $\mathrm{C}$ subfamilies according to their amino-acid sequences $[1,2]$. These chemokines are so named because they are cytokines that induce chemotaxis of leukocyte subsets and are expressed in a wide range of cell types and tissues $[1,2]$.

Chemokines have been found to be produced by an array of both immune and nonimmune cells and their secretion is typically induced by pro-inflammatory cytokines such as interleukin (IL)-1, IL-2, tumour necrosis factor (TNF)- $\alpha$, interferon (IFN)- $\gamma$, as well as viruses, bacterial products such as lipopolysaccharide (LPS), and complement fraction (C)5a and leukotriene (LT)B $\mathrm{B}_{4}[1,3]$.

Chemokines may play a pivotal role in orchestrating inflammation in pulmonary diseases. In fact, their presence and role has recently been studied in the biopsies and bronchoalveolar lavage fluid (BALF) of asthmatics [4, 5], in bacterial and fungal pneumonia $[6,7]$ and in interstitial lung diseases $[8,9]$.

To the authors knowledge, no data are available on the presence of CC chemokines or their role in chronic bron- chitis. Chronic bronchitis is characterized clinically by chronic cough, sputum production, and recurrent exacerbations [10], and is associated with mucosal inflammation characterized by mononuclear cell infiltration [11] and increased neutrophils in submucosal glands [12] and airways lumen $[13,14]$.

The pathogenesis and the identification of cells and mediators sustaining inflammation in the airways of patients affected by chronic bronchitis are still poorly understood. While the role of factors such as IL-8 [15-17], involved in the chemotaxis and activation of neutrophils has been largely investigated, very few data are available on the role of chemokines in the recruitment of mono-nuclear cells in smokers and chronic bronchitics.

This study evaluated three CC chemokines mainly involved in the recruitment of mononuclear cells: monocyte chemotactic protein-1 (MCP-1), macrophage inflammatory protein-1 $\alpha$ (MIP-1 $\alpha)$ and macrophage inflammatory protein-1 $\beta$ (MIP-1 $\beta)$. Their concentrations were evaluated in the BALF of patients affected by chronic bronchitis, with the aim of better understanding their role in the mechanisms 
of cell recruitment and in the maintenance of chronic inflammation of the bronchial mucosa.

\section{Methods}

\section{Study population}

The study population consisted of 47 subjects. Informed consent was obtained from each subject, and the protocol was approved by the Review Board at the Medical Center of Rehabilitation in Veruno, Italy.

Four groups were studied: control nonsmokers $(n=15)$, control smokers $(n=14)$, control exsmokers of $>5$ yrs standing $(n=6)$ and smokers affected by chronic bronchitis $(n=12)$. Table 1 shows the demographic and functional data of these groups.

Chronic bronchitis was diagnosed according to the American Thoracic Society criteria [10], as the presence of chronic productive cough for 3 months in two successive years in a patient in whom other causes of chronic cough could be excluded.

Each subject underwent interview, chest radiography, electrocardiography (ECG), routine blood test, skin tests with common allergen extracts (pollen, house dust mites, animal furs, fungal spores), and pulmonary function tests.

Patients with respiratory disorders other than chronic bronchitis, including autoimmune disorders, infectious diseases, immunodeficiency conditions, malignancies or clinically significant cardiovascular, neurological, endocrine or haematological disorders, were excluded. Patients had to be nonatopic (negative skin tests with common allergen extracts) and have no past history of asthma or allergic rhinitis.

Patients were not studied within two months of an exacerbation and only treatment with bronchodilators, without steroid or nonsteroidal antinflammatory drugs, was permitted.

\section{Pulmonary function tests}

Pulmonary function testing included the measurement of forced expiratory volume in one second (FEV1), forced vital capacity (FVC) and FEV1/FVC (6200 Autobox Pulmonary Function Laboratory; Sensormedics Corp., Yorba Linda, CA, USA). In order to assess the reversibility of airway obstruction in patients with chronic bronchitis, FEV1 measurement was repeated 15 min after inhalation of $200 \mu \mathrm{g}$ salbutamol. A reversibility $>10 \%$ was an exclusion criteria of the study. In three patients with FEV $1>80 \%$ of predicted, the presence of hyperreactivity of the airways was excluded using a methacoline bronchoprovocation test.

\section{Bronchoscopy}

All subjects were premedicated intramuscularly with atropine $(0.5 \mathrm{mg})$ and diazepam $(10 \mathrm{mg})$ and orally with dihydrocodein $(10 \mathrm{mg})$. Oropharynx and larynx were anaesthetized topically with 2 and $10 \%$ lidocaine, respectively, before the bronchoscopy. Bronchoscopy was performed with a flexible fibreoptic bronchoscope (Pentax FB-18P; Asahi Optical Co. Ltd., Tokyo, Japan) and BAL was performed with a total of $150 \mathrm{~mL}$ of prewarmed $\left(37^{\circ} \mathrm{C}\right)$ sterile isotonic saline instilled in aliquots of $50 \mathrm{~mL}$, in the right middle lobe and immediately recovered by syringe with manual suction. The bronchoscopy with BAL was well tolerated by all subjects and the safety was recorded with ECG and pulse oximetry.

\section{Processing of bronchoalveolar lavages}

The total fluid recovered by BAL was processed as previously described [18]. Fluids were filtered through a monolayer of sterile gauze. Cytocentrifuge (Cytospin II; Shandon, London, UK) slides, prepared with native fluid, were stained with May-Grünwald Giemsa to determine the differential cell count. A total of at least 500 cells (without epithelial cells) per slide was examined at $\times 1,000$ magnification. The cytocentrifuge slides used for immunocytochemistry were fixed for $2 \mathrm{~min}$ with aceton and frozen at $-80^{\circ} \mathrm{C}$ until analysis.

BAL cells were separated from lavage fluid by refrigerated $\left(4^{\circ} \mathrm{C}\right)$ centrifugation (Beckman TJ 6; Beckman Instruments, Fullerton, CA, USA) at $400 \times g$ for $15 \mathrm{~min}$, and supernatants were immediately stored at $-80^{\circ} \mathrm{C}$ until analysis.

\section{Immunocytochemistry}

The expression of MIP- $1 \alpha$, MIP- $1 \beta$ and MCP- 1 in BAL cells was assessed by immunocytochemistry on frozen cytocentrifuge slides. The rabbit polyclonal antibodies anti-MIP- $1 \alpha$ and anti MIP-1 $\beta$ were kindly provided by L.A. Mills (National Institutes of Health (NIH), Bethesda, MD, USA) and the anti-MCP-1 mouse monoclonal antibody was purchased from Chemicon International, Inc. (Temecula, CA, USA). Monoclonal antibody binding was detected with the alkaline phosphatase anti-alkaline phosphatase method (Dako APAAP kit system; Dako, Copenhagen, Denmark) and fast-red substrate.

Table 1. - Demographic and functional data of study population

\begin{tabular}{|c|c|c|c|c|c|}
\hline & \multicolumn{3}{|c|}{ Control } & \multirow{2}{*}{$\begin{array}{l}\text { Chronic bronchitis } \\
\text { (smokers) }\end{array}$} & \multirow[b]{2}{*}{ p-value ${ }^{+}$} \\
\hline & Nonsmokers & Smokers & Exsmokers & & \\
\hline Subjects $n$ & 15 & 14 & 6 & 12 & \\
\hline Age & $47.5 \pm 14.5$ & $49.3 \pm 13.3$ & $61.5 \pm 7.3^{*}$ & $62.7 \pm 9.0^{*}$ & 0.0078 \\
\hline $\mathrm{Sex} \mathrm{M} / \mathrm{F}$ & $8 / 7$ & $10 / 4$ & $6 / 0$ & $10 / 2$ & \\
\hline FEV1 \% pred & $105.2 \pm 14.4$ & $105.6 \pm 15.3$ & $95.5 \pm 10.8$ & $69.5 \pm 14.8^{* * *}$ & 0.0001 \\
\hline$\Delta \mathrm{FEV} 1$ from baseline (after salbutamol) & - & - & - & $5.0 \pm 2.0$ & - \\
\hline FVC $\%$ pred & $105.7 \pm 14.8$ & $108.7 \pm 17.1$ & $101.0 \pm 17.8$ & $81.8 \pm 13.7^{\S}$ & 0.0003 \\
\hline FEV $1 /$ FVC $\%$ & $84.4 \pm 4.7$ & $82.3 \pm 9.4$ & $80.9 \pm 6.1$ & $69.0 \pm 7.5^{\S}$ & 0.0003 \\
\hline
\end{tabular}

Data are presented as mean $\pm \mathrm{SD} .{ }^{+}:$Kruskal-Wallis test. M: male; F: female; FEV1: forced expiratory volume in one second; FVC: forced vital capacity. ${ }^{*} \mathrm{p}=0.007$ versus control nonsmokers and smokers; ${ }^{\S}, * * *: \mathrm{p}=0.005, \mathrm{p}=0.001$ versus control groups. 
Table 2. - Characteristics of bronchoalveolar lavage fluid from the study population

\begin{tabular}{|c|c|c|c|c|c|}
\hline & \multicolumn{3}{|c|}{ Control } & \multirow{2}{*}{$\begin{array}{l}\text { Chronic bronchitis } \\
\text { (smokers) }\end{array}$} & \multirow[b]{2}{*}{ p-value ${ }^{+}$} \\
\hline & Nonsmokers & Smokers & Exsmokers & & \\
\hline Subjects n & 15 & 14 & 6 & 12 & \\
\hline Recovery mL & $76.4 \pm 18.4$ & $67.4 \pm 17.3$ & $67.2 \pm 14.3$ & $60.4 \pm 13.9^{\# \#}$ & 0.0455 \\
\hline Cell number $10^{3}$ cells $\cdot \mathrm{mL}^{-1}$ & $118.7 \pm 48.6$ & $304.4 \pm 199.5^{\S}$ & $144.8 \pm 69.9$ & $281.2 \pm 183.1^{\S}$ & 0.0015 \\
\hline Macrophages \% & $88.1 \pm 6.6$ & $91.7 \pm 6.0$ & $89.3 \pm 9.4$ & $84.3 \pm 10.5$ & NS \\
\hline Lymphocytes \% & $9.7 \pm 6.5$ & $4.6 \pm 5.9$ & $7.5 \pm 7.5$ & $7.8 \pm 7.3$ & NS \\
\hline Neutrophils \% & $1.6 \pm 0.7$ & $3.2 \pm 3.0$ & $3.3 \pm 3.9$ & $6.9 \pm 7.2^{*}$ & 0.0132 \\
\hline Eosinophils \% & $0.5 \pm 0.4$ & $0.5 \pm 0.5$ & $0.7 \pm 0.5$ & $0.9 \pm 1.0$ & NS \\
\hline Basophils \% & $0.1 \pm 0.3$ & $0.04 \pm 0.05$ & $0.1 \pm 0.2$ & $0.1 \pm 0.2$ & NS \\
\hline Macrophages $10^{3}$ cells $\cdot \mathrm{mL}^{-1}$ & $105.8 \pm 47.1$ & $286.8 \pm 193.3^{\S}$ & $127.2 \pm 65.5$ & $251.5 \pm 93.6^{\S}$ & 0.0041 \\
\hline Lymphocytes $10^{3}$ cells $\cdot \mathrm{mL}^{-1}$ & $10.5 \pm 8.2$ & $8.4 \pm 9.0$ & $12.1 \pm 6.7$ & $17.3 \pm 8.8$ & NS \\
\hline Neutrophils $10^{3}$ cells $\cdot \mathrm{mL}^{-1}$ & $1.8 \pm 1.2$ & $6.5 \pm 7.6^{\#}$ & $4.6 \pm 3.5^{* *}$ & $10.2 \pm 11.6^{\#}$ & 0.0014 \\
\hline Eosinophils $10^{3}$ cells $\cdot \mathrm{mL}^{-1}$ & $0.5 \pm 0.4$ & $1.5 \pm 2.5$ & $0.8 \pm 0.7$ & $1.7 \pm 2.8$ & NS \\
\hline Basophils $10^{3}$ cells $\cdot \mathrm{mL}^{-1}$ & $0.1 \pm 0.3$ & $0.1 \pm 0.2$ & $0.1 \pm 0.2$ & $0.1 \pm 0.2$ & NS \\
\hline
\end{tabular}

Data are presented as mean $\pm \mathrm{SD} .{ }^{+}:$Kruskal-Wallis test. NS: nonsignificant. ${ }^{*}: \mathrm{p}=0.0073$ versus control nonsmokers and $\mathrm{p}=0.045$ versus

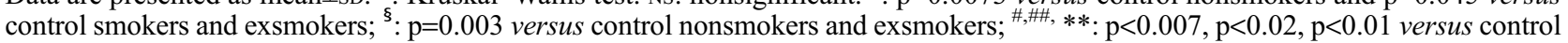
nonsmokers (Mann-Whitney U-test).

Cytospin preparations of LPS-stimulated mononuclear cells were used as a positive control in each staining run [3]. Negative control slides included cytospin preparations immunostained with mouse monoclonal immunoglobulin (Ig)G2a (X943; Dako) and rabbit immunoglobulins from normal rabbit serum.

\section{Immunoassay}

The concentrations of the chemokines in BALF were obtained with Quantikine MIP-1 $\alpha$, MIP $1 \beta$ and MCP-1 enzyme-linked immunosorbent assay (ELISA) kits purchased from R\&D Systems (Abington, UK). These assays employ the quantitative sandwich enzyme immunoassay technique. The lower limits of detection of the kits (manufacturer's data) were as follows: MIP- $1 \propto 6.0 \mathrm{pg} \cdot \mathrm{mL}^{-1}$; MIP$1 \beta 4.0 \mathrm{pg} \cdot \mathrm{mL}^{-1}$; MCP-1 $5.0 \mathrm{pg} \cdot \mathrm{mL}^{-1}$.

All BALFs were concentrated 5-fold with Centricon-3 (3 kDa cut-off) concentrators (Amicon Inc., Beverly, MA, USA) and run in duplicate. The results obtained were divided for the concentration value.

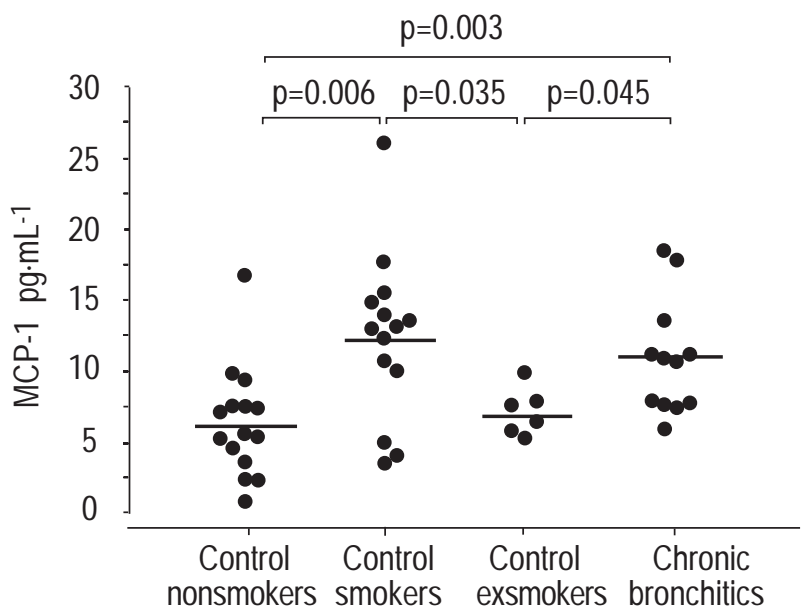

Fig. 1. - Levels of monocyte chemotactic protein-1 (MCP-1) immunoreactivity in bronchoalveolar lavage fluid supernatants from control nonsmokers $(n=15)$, smokers $(n=14)$ and exsmokers $(n=6)$ and chronic bronchitic subjects $(n=12)$. Horizontal bars represent mean values.

\section{Statistical analysis}

Data are reported as mean \pm SD. Differences between the four groups were assessed with the Kruskal-Wallis and Mann-Whitney U-tests. The Spearman's rank correlation coefficient was used to study correlations between chemokine concentrations and both pulmonary function tests and cellular populations of BALF. Analysis was performed with a microcomputer (Macintosh LC; Apple Inc., Cupertino, CA, USA) and Statview + Graphics software (Abacus Concepts Inc., Berkeley, CA, USA). Statistical significance was defined as $\mathrm{p} \leq 0.05$.

\section{Results}

While the groups of control exsmokers and patients affected by chronic bronchitis were older $(p=0.007)$ than nonsmoker or smoker control subjects, no correlations were found between chemokine levels in the BALF and the age of subjects. No difference in smoking habit was present between smoker controls and chronic bronchitics (41.9 \pm 21.1 pack-yrs versus $49.4 \pm 35.8$ pack-yrs) and no dose-dependent relationship was observed with the chemokine increases.

A significant $(\mathrm{p}<0.001)$, mild airways obstruction was present in patients with chronic bronchitis (table 1).

The BALF analysis results are shown in table 2. BALF recovery was significantly lower in patients affected by chronic bronchitis than in the nonsmoker control group $(p=0.02)$. The total number of cells and macrophages in BALF was significantly higher in both control smokers and chronic bronchitics versus nonsmokers and exsmokers.

Patients affected by chronic bronchitis showed a significant increase in the percentage of neutrophils with respect to all control groups. When the absolute numbers of these cells were compared, the differences between chronic bronchitics $\left(10.2 \pm 11.6 \times 10^{3}\right.$ neutrophils $\left.\cdot \mathrm{mL}^{-1}\right)$, control smokers $\left(6.5 \pm 7.6 \times 10^{3}\right.$ neutrophils $\left.\cdot \mathrm{mL}^{-1}\right)$ and control exsmokers $\left(4.6 \pm 3.5 \times 10^{3}\right.$ neutrophils $\left.\cdot \mathrm{mL}^{-1}\right)$ were not statistically significant.

In the cytospin preparations of all subjects, ciliated epithelial cells and $>80 \%$ of alveolar macrophages were 


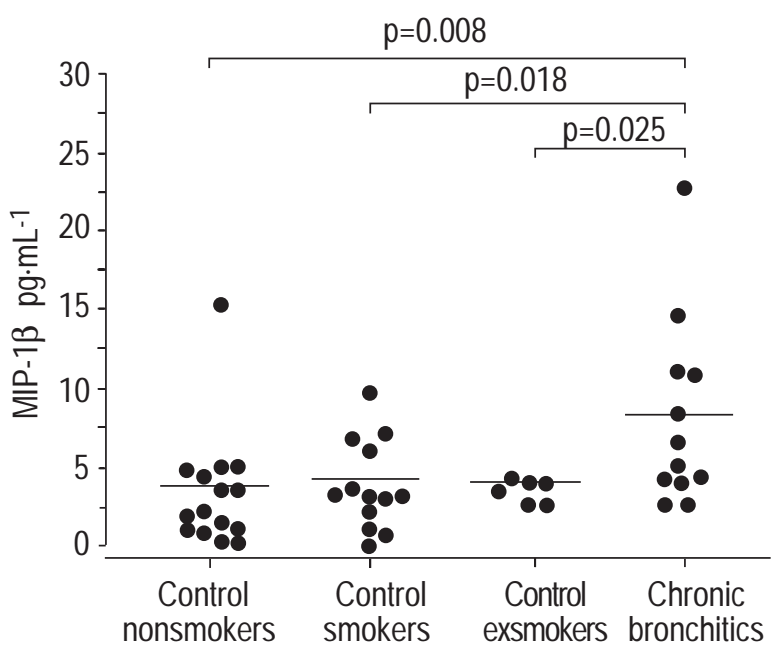

Fig. 2. - Levels of macrophage inflammatory protein-1 $\beta$ (MIP-1 $\beta$ ) immunoreactivity in bronchoalveolar lavage fluid supernatants from control nonsmokers $(n=15)$, smokers $(n=14)$ and exsmokers $(n=6)$, and chronic bronchitic subjects $(\mathrm{n}=12)$. Horizontal bars represent mean values.

positively immunostained for MIP-1 $\alpha$, MIP- $1 \beta$ and MCP-1 proteins. It was observed that macrophages with cytoplasm heavily laden by haemosiderin-like residues or anthracotic particles were negatively immunostained for the three chemokines.

The concentrations of MCP-1 in BALF are shown in figure 1. Significantly higher levels were observed in both groups of smokers, i.e. controls and chronic bronchitics $\left(12.39 \pm 5.87\right.$ and $10.75 \pm 4.04 \mathrm{pg} \cdot \mathrm{mL}^{-1}$, respectively), than in nonsmoker $\left(6.41 \pm 3.87 \mathrm{pg} \cdot \mathrm{mL}^{-1} ; \mathrm{p}=0.006\right.$ and $\mathrm{p}=0.003$, respectively) or exsmoker $\left(7.12 \pm 1.6 \mathrm{pg} \cdot \mathrm{mL}^{-1} ; \mathrm{p}=0.045\right.$ and $\mathrm{p}=0.035$, respectively) controls.

The concentrations of MIP- $1 \alpha$ in 5-fold concentrated BALF of the four groups were undetectable. The MIP-1 $\beta$ levels are shown in figure 2 . Significantly higher concentrations were found in patients affected by chronic bronchitis $\left(8.11 \pm 5.97 \mathrm{pg} \cdot \mathrm{mL}^{-1}\right)$ than in nonsmoker $(3.39 \pm 3.73$ $\left.\mathrm{pg} \cdot \mathrm{mL}^{-1}, \mathrm{p}=0.008\right)$, smoker $\left(3.57 \pm 2.90 \mathrm{pg} \cdot \mathrm{mL}^{-1}, \mathrm{p}=0.018\right)$ or exsmoker controls $\left(3.43 \pm 0.68 \mathrm{pg} \cdot \mathrm{mL}^{-1}, \mathrm{p}=0.025\right)$.

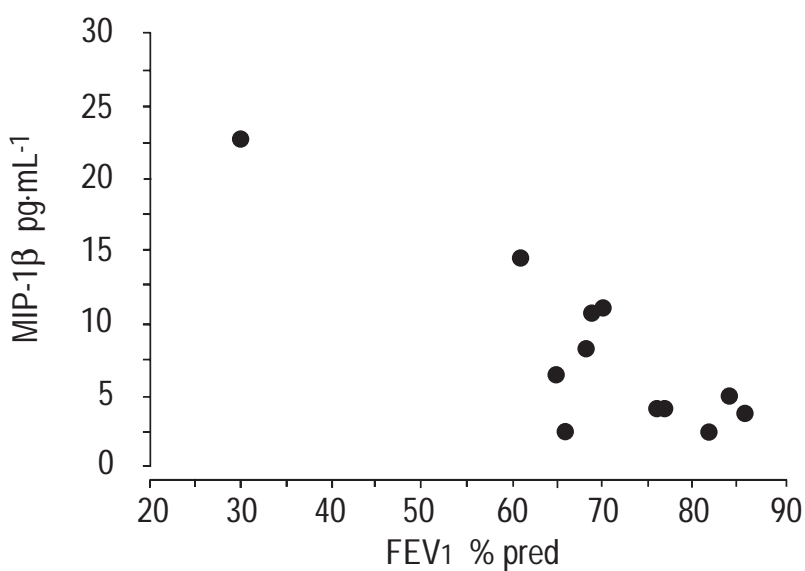

Fig. 3. - Correlation between forced expiratory volume in one second (FEV1) and macrophage inflammatory protein-1 $\beta$ (MIP-1 $\beta$ ) levels in bronchoalveolar lavage fluid supernatants from patients affected by chronic bronchitis $(n=12) . r=-0.64 ; p=0.035$.
No significant correlations were obtained comparing BALF cytological data or functional parameters with the concentrations of MCP-1. Conversely, a negative correlation between FEV1 (\% pred) and MIP-1 $\beta$ levels in BALF of patients affected by chronic bronchitis was observed ( $\rho=-0.64, p=0.035$ ) (fig. 3 ), although restricting the population to chronic bronchitics with mild to moderate obstruction (FEV1 $\geq 60 \%$ pred) did not yield any significant relationship $(\rho=-0.53, p=0.09)$.

\section{Discussion}

This study shows that smoking habit induces a significant increase of MCP-1 levels in the BALF of healthy control subjects and patients with chronic bronchitis. Conversely, the concentrations of MIP-1 $\beta$ are increased only in smoker patients affected by chronic bronchitis, and correlate with the degree of airflow limitation. These results support the hypothesis of an involvement of the CC-chemokines in the inflammatory reaction to cigarette smoke and in the maintenance of inflammation in chronic bronchitis.

Chronic bronchitis is an inflammatory disease, induced principally, but not only, by tobacco smoke, associated with infiltration of leukocytes such as lymphocytes, macrophages [11], neutrophils $[13,14]$ and eosinophils during an exacerbation [19]. Cigarette smoke, even in subjects without bronchial disease, is able to induce a dosedependent inflammatory reaction in the respiratory tract, with the recruitment of macrophages and neutrophils and an increase in some cytokines, including MCP-1 [20]. On the other hand, chronic bronchitis in nonsmokers is not associated with a significant increase of macrophages in BALF [14]. The present data confirm that neutrophils, macrophages and MCP-1 show an increased concentration in BALF of control smokers, observations which have been extended by also showing an increase of this chemokine in the BALF of chronic bronchitics. The authors did not find a dose-dependent relationship between MCP-1 concentrations in BALF and the smoking habit. However the involvement of the smoking habit is sustained by the observation of an MCP-1 decrease after smoking cessation in the group of exsmoker subjects. The role of MCP-1 in smokers is probably to recruit monocytes from the blood to increase the airways and alveolar macrophage population as a reactive barrier against foreign agents. This speculation is sustained by the observed role of MCP-1 in the clearance of a Cryptococcus neoformans infection [7] and, more generally, by the role of chemokines in bacterial and viral infections $[6,21]$. However, since no correlation between the number of alveolar macrophages in BALF and the level of MCP-1 was found, it is likely that this chemokine is only one among several factors responsible for the recruitment of macrophages in the bronchial lumen and alveolar space; moreover, this recruitment depends not only on the gradient of chemokines, but also on several successive steps, including adherence, rolling and extravasion, regulated by proinflammatory cytokines.

More than $80 \%$ of these alveolar macrophages were positively immunostained for the chemokines in all subjects studied. Conversely there were significant differences in the concentrations of these proteins in the BALF of different 
groups. This apparent discrepancy might be due to the difficulty in comparing the cellular content of chemokine evaluated by immunostaining and the levels in BALF as quantified by ELISA. When some of these macrophages, as the authors have observed, are engulfed by haemosiderinlike residues or anthracotic particles, they are negatively immunostained for MCP-1, MIP- $1 \alpha$ and MIP-1 $\beta$, suggesting a release or a reduced production of these chemokines.

An MCP-1 increase in BALF has been observed after many other types of pulmonary injury such as that owing to dust exposure [9] and organic antigen exposure [22], suggesting that this increase may be part of an early pulmonary inflammatory reaction to an injury.

The degree of concentration (5-fold) of the BALF supernatants in this study was not high enough to detect MIP-1 $\alpha$ with the ELISA kit used, but it was demonstrated that the levels of this chemokine are lower than those of MIP-1 $\beta$. It was also observed that MIP- $1 \beta$ concentrations in BAL were higher in chronic bronchitic patients than in control groups.

MIP-1 $\beta$ has rarely been considered in lung diseases, and this study is the first evaluation of BALF levels of this chemokine in normal and chronic bronchitic subjects. The studies on MIP-1 $\beta$ to date are too limited to clarify the role of this CC-chemokine in the pathogenesis of bronchial and pulmonary inflammatory diseases. SCHRUM et al. [23] observed that MIP-1 $\beta$ is secreted by T-lymphocytes, particularly by those T-cell clones that display an IL-2 and IFN- $\gamma$ cytokine pattern, indicative of a T-helper type 1 (Th-1)-like phenotype. There is some evidence that in patients with chronic obstructive pulmonary disease, Tlymphocytes in the lower respiratory tract might be of the Th-1 subset [24]. The observation in this study of increased MIP-1 $\beta$ concentrations in the airways of patients with chronic bronchitis could support this hypothesis.

The authors recently reported a direct relationship between the severity of airflow limitation and the degree of airway inflammation [25]; the present finding of a correlation between increased levels of MIP-1 $\beta$ in BALF and the degree of airflow limitation might indicate an involvement of this chemokine in the progression of chronic obstructive pulmonary disease, but further confirmation is needed in a larger population of chronic bronchitics, including those with severe disease.

In conclusion, these results suggest a possible role of the monocyte chemotactic protein 1 chemokine in early host defence mechanisms of smokers and an involvement of macrophage inflammatory protein- $1 \beta$ in the pathogenesis and inflammatory pathology of chronic bronchitis.

\footnotetext{
Acknowledgments. The authors thank R. Allpress for editorial assistance, and M. Colombo and N. Novello for technical assistance.
}

\section{References}

1. Strieter RM, Standiford TJ, Huffnagle GB, Colletti LM, Lukacs NW, Kunkel SL. "The good, the bad, and the ugly". The role of chemokines in models of human disease. J Immunol 1996; 156: 3583-3586.

2. Adams DH, Lloyd AR. Chemokines: leukocyte recruitment and activation cytokines. Lancet 1997; 349: 490495.
3. Baggiolini M, Dewald D, Moser B. Interleukin- 8 and related chemotactic cytokines: $\mathrm{CXC}$ and $\mathrm{CC}$ chemokines. Adv Immunol 1994; 55: 97-179.

4. Sousa AR, Lane SJ, Nakhosteen JA, Yoshimura T, Lee $\mathrm{TH}$, Poston RN. Increased expression of the monocyte chemoattractant protein-1 in bronchial tissue from asthmatic subjects. Am J Respir Cell Mol Biol 1994; 10: 142147.

5. Cruikshank WW, Long A, Tarpy RE, et al. Early identification of interleukin-16 (lymphocyte chemoattractant factor) and macrophage inflammatory protein $1 \alpha$ (MIP-1 $\alpha$ ) in bronchoalveolar lavage fluid of antigenchallenged asthmatics. Am J Respir Cell Mol Biol 1995; 13: 738-747.

6. Standiford TJ, Strieter RM, Greenberger MJ, Kunkel SL. Expression and regulation of chemokines in acute bacterial pneumonia. Biol Signals 1996; 5: 203-208.

7. Huffnagle GB, Strieter RM, Standiford TJ, et al. The role of monocyte chemotactic protein-1 (MCP-1) in the recruitment of monocytes and CD4+ T cells during a pulmonary Cryptococcus neoformans infection. J Immunol 1995; 155: 4790-4797.

8. Petrek M, Pantelidis P, Southcott AM, et al. The source and role of RANTES in interstitial lung disease. Eur Respir J 1997; 10: 1207-1216.

9. Boitelle A, Gosset $\mathrm{P}$, Copin $\mathrm{MC}$, et al. $\mathrm{MCP}-1$ secretion in lung from nonsmoking patients with coal worker's pneumoconiosis. Eur Respir J 1997; 10: 557-562.

10. American Thoracic Society. Standards for the diagnosis and care of patients with chronic obstructive pulmonary disease. Am J Respir Crit Care Med 1995; 152: S77S120.

11. Di Stefano A, Turato G, Maestrelli P, et al. Air-flow limitation in chronic bronchitis is associated with Tlymphocyte and macrophage infiltration of the bronchial mucosa. Am J Respir Crit Care Med 1996; 153: 629-632.

12. Saetta M, Turato G, Facchini FM, et al. Inflammatory cells in the bronchial glands of smokers with chronic bronchitis. Am J Respir Crit Care Med 1997; 156: 16331639.

13. Thompson AB, Daughton D, Robbins GA, Ghafouri MA, Oehlerking M, Rennard SI. Intraluminal airway inflammation in chronic bronchitis: characterization and correlation with clinical parameters. Am Rev Respir Dis 1989; 140: $1527-1537$.

14. Lusuardi M, Capelli A, Cerutti CG, Spada EL, Donner CF. Airways inflammation in subjects with chronic bronchitis who have never smoked. Thorax 1994; 49: 12111216.

15. Keatings VM, Collins PD, Scott DM, Barnes PJ. Differences in interleukin-8 and tumor necrosis factor-a in induced sputum from patients with chronic obstructive pulmonary disease or asthma. Am J Respir Crit Care Med 1996; 153: 530-534.

16. Mio T, Romberger DJ, Thompson AB, Robbins RA, Heires A, Rennard SI. Cigarette smoke induces interleukin-8 release from human bronchial epithelial cells. Am J Respir Crit Care Med 1997; 155: 1770-1776.

17. Pesci A, Balbi B, Majori M, et al. Inflammatory cells and mediators in bronchial lavage of patients with chronic obstructive pulmonary disease. Eur Respir $J$ 1998; 12: 380-386.

18. Capelli A, Lusuardi M, Carli S, Donner CF. Acid phosphatase (E.C 3.1.3.2.) activity in alveolar macrophages from patients with active sarcoidosis. Chest 1991; 99: $545-550$. 
19. Saetta M, Di Stefano A, Maestrelli P, et al. Airway eosinophilia in chronic bronchitis during exacerbations. Am J Respir Crit Care Med 1994; 150: 1646-1652.

20. Kuschner WG, D'Alessandro A, Wong H, Blanc PD. Dose-dependent cigarette smoking-related inflammatory responses in healthy adults. Eur Respir J 1996; 9: 19891994.

21. Friedland JS. Chemokines in viral disease. Res Virol 1996; 147: 131-138.

22. Sugiyama Y, Kasahara T, Mukaida N, Matsushima K, Kitamura S. Chemokines in bronchoalveolar lavage fluid in summer-type hypersensitivity pneumonitis. Eur Respir $J$ 1995; 8: 1084-1090.
23. Schrum S, Probst P, Fleischer B, Zipfel PF. Synthesis of the CC-chemokines MIP-1 alpha, MIP-1 beta, and RANTES is associated with the type 1 immune response. $J$ Immunol 1996; 157: 3598-3604.

24. O'Shaughnessy TC, Ansari TW, Barnes NC, Jeffery PK. Inflammation in bronchial biopsies of subjects with chronic bronchitis: inverse relationship of CD8+ T lymphocytes with FEV1. Am J Respir Crit Care Med 1997; 155: 852-857.

25. Di Stefano A, Capelli A, Lusuardi M, et al. Severity of airflow limitation is associated with severity of airway inflammation in smokers. Am J Respir Crit Care Med 1998; 158: 1277-1285. 